\title{
Managing for Sustainability: The Development of Environmental Flows Implementation in China
}

\author{
Ang Chen ${ }^{1}(1)$ and Miao $\mathrm{Wu}^{2, *}$ \\ 1 State Key Laboratory of Simulation and Regulation of Water Cycle in River Basin, China Institute of Water \\ Resources and Hydropower Research, Beijing 100038, China; angteenchen@gmail.com \\ 2 College of Hydrology and Water Resources, Hohai University, Nanjing 210098, China \\ * Correspondence: 3water@hhu.edu.cn; Tel.: +86-157-5187-0080
}

Received: 11 January 2019; Accepted: 25 February 2019; Published: 28 February 2019

check for updates

\begin{abstract}
Environmental flows (e-flows) are important for river protection and restoration under degraded ecological conditions. With increasing public desire for and pursuit of sustainable development, e-flows are widely used to reflect the hydrological regime requirements for sustaining freshwater ecosystems and human livelihoods. Over the past 40 years, e-flows implementation has shifted from static minimum flows to dynamic flow components. However, e-flows standards used to manage flow releases from dams are to a great extent based on expert judgement and government supervision. These attributes make it difficult to effectively implement e-flows in the non-stationary world. The primary focus of this paper is to review the history, management systems and scientific basis of e-flows in China. Firstly, the study classifies the development phases into four periods and then analyses the underpinning legal system for e-flows implementation in each period, including the laws, regulations, policies and responsible authorities. Finally, the scientific basis and methods for e-flows determination and assessment were analyzed. The study showed that: (1) e-flows have been officially regarded as ecological flow in China, which evolved from minimum flow, and the contents and connotations are still broadening; (2) currently, there are too many authorities related to e-flows and complicated legal documents in China which lead to ineffective implementation; (3) the scientific basis of e-flows is enriched from the relationship between hydrological alteration and ecological response, so that the practices will be more holistic in China. Despite the successful practices of e-flows implementation in large rivers, there are challenges for implementing future e-flows in small rivers. This study recommended that future e-flows implementation be integrated with sustainable water management by setting clear responsibilities for governments, ministries, and other stakeholders.
\end{abstract}

Keywords: environmental flows; ecological flow; freshwater ecosystem; hydrological regime; water governance

\section{Introduction}

Environmental flows (e-flows) lie in ecological science and environmental realms. The concept of e-flows was historically developed in response to the degradation of aquatic ecosystems caused by the overuse of water [1]. In many countries, minimum flow requirements were estimated in the initial stage of water allocation, due to data limitations [2]. It was not until the flow-ecology relationship was proposed that the adaptive management loop of effective e-flows implementation closed [3]. Next, adaptive management promoted the optimization of e-flows by quantifying the ecological response to hydrological alteration, and ensured the effectiveness of the implemented management actions [4-6]. The scientific basis was then enriched from economic integration and modelling development $[7,8]$. However, managing sustainable water planning through e-flows requires 
more holistic integration between science and practice to bridge the gap among scientists, engineers, managers and other stakeholders, especially in developing countries $[9,10]$. Sustainability is a balancing act. The United Nation's 1987 Report of the World Commission on Environment and Development noted that sustainable development meets the needs of the present without compromising the well-being of future generations. The concept has continued to expand in scope. The new 2030 Agenda for Sustainable Development represented a significant step forward for the integration of e-flows into Integrated Water Resources Management (IWRM). In order to achieve China's 2030 sustainable development goals for ecological systems, managers have to ensure that river base flows and variable flows meet the requirements of all ecosystem objectives. In addition, scientific knowledge suggests that the flow-ecology relationships and adaptive management of Chinese government must be enhanced in the non-stationary world [11].

E-flows were first defined in the Brisbane Declaration in 2007 and revised in 2018 [12]. Since then, e-flows releases have become one of the main issues in the operation period of dam projects, while increased dam projects have led to the degradation of river ecosystems [13]. The development of e-flows in China has been similar to other countries, and a common definition was achieved in 2006. It was defined as the amount of water reserved for aquatic ecosystems, or released into them, for the specific purpose of maintaining the status of aquatic ecosystems. Over the past several decades, the implementation of e-flows adaptive management on hundreds of dam projects has promoted scientific research and management [14]. As a result, many policies and regulations for guiding e-flows determination and assessment throughout the management process were published. However, there are too many authorities responsible for e-flows management, as well as too many ineffective regulations with varying measures of success. As a result, the release of e-flows has been based to a great extent on expert judgement and government supervision rather than standardized guidelines. Given the complexity and relative uncertainty inherent in the relationships between e-flows and environmental objectives, e-flows management systems must be adaptive.

This study reviewed the development of e-flows implementation in China. Then, the temporal period classification and relevant policies and institutions were assessed. The review concludes with a discussion regarding the future directions of scientific research based on integration of e-flows with national policies, as well as recommendations for the management of environmental sustainability.

\section{History}

\subsection{Emergence}

The history of e-flows in China can be traced back to the 1970s, originating in northwestern China. The origin of e-flows arose from the discussion of minimum flows, which focused on the minimum flow determination in northwestern China [15]. After the book "Limits to Growth" was published in 1972, its findings sparked a worldwide controversy about the Earth's capacity to withstand constant human and economic expansion. As a result, the first Chinese environmental agency was set up, and in 1973 the National Environmental Protection Institution was founded. E-flows' relevant concepts were introduced to China during this period with several implementations of minimum flows. However, water resource agencies were the implementation authorities, and a river-by-river assessment of minimum flows was performed. In addition, some achievements such as the "Primary Discussion on Environmental Flow Demand" were published during this time. There were no clear definitions of e-flows and sustainable water uses, and the implementations focused on maintaining the minimum flow for hydrological connectivity.

\subsection{Development}

E-flows in China were developed in the 1980s, while global sustainable research advanced. Sustainable development was first defined in "Our Common Future" by the World Commission on Environment and Development in 1987. China's Environment Protection Agency was founded from 
the National Environmental Protection Institution in 1982. For water pollution prevention in most rivers and lakes, environmental water assessment was required and addressed in the national water resource planning issued by Chinese State Council, along with the introduction of global e-flows methods. Environmental and water resource institutions worked together on e-flows during this period, stressing the maintenance of water for hydrological connectivity and prevention of water pollution. Some representative achievements during this period were the "Allocation Plan of Yellow River's Available Water Supply" issued by the State Council in 1987, which is still in use today, and the "Handbook on Water Resource Protection" published in 1988. Most important was the publication of the "Environmental Protection Law of the People's Republic of China" in 1989. These documents and their philosophies guided the primary water use practice in China, and promoted scientific research of sustainable water use.

\subsection{Expansion}

E-flows research and practices expanded in the 1990s. With the publication of the "Rio Declaration" and "Agenda 21", China developed the "China Agenda 21" in 1992, aimed at the sustainable development of the society, economy and environment. River ecosystem protection and restoration became the main focuses of e-flows implementation, while the contradictions of water users became increasingly acute. E-flows were derived from multiple relevant concepts such as ecological flow, ecological suitable flow, ecological acceptable flow, etc., and the methods were widely applied in different regions and basins [16]. Taking regional differences and functional diversities into consideration, e-flows shifted from rivers to project-specific assessment during this period [17]. Despite the fact that methods and models were developed, and the e-flows were considered in water resource planning and allocation, the problems among water uses remained acute due to ineffective management.

\subsection{Consolidation and Challenges}

Since the turn of the 21st century, the implementation of e-flows has improved [18]. The "Law of the People's Republic of China on Environmental Impact Assessment" was published in 2002, and set the EIA as the prefix condition of project construction. During this period, the State Environmental Protection Administration and Ministry of Water Resources cooperated with environmental flow management. It was not until 2006 that the official e-flows determination regulation (Technical Guide for Environmental Impact Assessment of River Ecological Flow, Cold Water, and Fish Passage Facilities for Water Conservation Construction Projects (Trial), "Technical Guide 2006" for short) was issued by the State Environmental Protection Administration. And 10\% of the annual average flow was set as the minimum flow that a dam project should release in the Environment Impact Assessment (EIA) phase. While the minimum flow was more operable, the holistic considerations were less operable in implementation without scientific assessment and strict supervision [19]. After the "Brisbane Declaration" was released in 2007, more social water demand and sustainable projects were integrated into China's e-flows management system by reinforcing the technical guide. And e-flows determinations were improved year by year through strict environmental management [20]. As early as the Third Plenary Session of the 18th CPC Central Committee in 2013, Chinese President $\mathrm{X} \mathrm{i}$ Jinping pointed out that we should realize that the country's mountains, rivers, forests, land and lakes form a community of shared life. Humanity and ecosystems form a community of shared life by which people construct ecological civilization and achieve the goal of "beautiful China", and this was further reinforced in the 19th Committee in 2017. To achieve the 2015 environmental sustainable development goals as defined by the Millennium Development Goals (MDG), China began national ecological civilization construction [21]. E-flows became important parts of water ecological civilization construction.

A greater transformation took place in 2015, when the 2030 Agenda for Sustainable Development was published, and China began to pursue green development and "beautiful China". The 
"Environmental Protection Law of People's Republic of China and the Law of the People's Republic of China on Environmental Impact Assessment" were updated with particular emphasis on e-flows. In addition, ecological compensation pilot demonstrations in some small hydropower projects were successful in releasing e-flows by feed-in tariffs. From the State Council to local governments, the philosophy of sustainable development became ubiquitous, and multiple ministries worked together for e-flows implementation. However, challenges arose among multiple ministries collaborating in the joint parts (e.g., river chief policy in connection with hydropower projects, and power dispatching in connection with water regulation).

\section{Management System}

\subsection{Responsible Institutions}

Multiple ministries have been involved in the management of e-flows in China. More than 20 ministries are set under the State Council of Chinese Government, and there are as many as nine ministries involved in e-flows management. The Ministry of Environment Protection (MEP), Ministry of Water Resources (MWR) and the National Energy Administration (NEA) are the three main ministries responsible for e-flows implementation, ranging from the planning to the construction of dam projects (Table 1). The MEP is responsible for e-flows release determination in the planning and design period, which is enforced in Plan-EIA and EIA for water relevant projects. "Three Simultaneities" is the major measure for guaranteeing e-flows releases in the construction period, and there are still no effective measures of e-flows releases in the operation period. E-flows release optimization and adaptive management methods though post-project EIA are currently under discussion. The MWR is mainly responsible for e-flows protection in freshwater ecosystems and e-flows pre-assessment before Plan-EIA and EIA, which are mainly undertaken in the water resource allocation in the plan and design period. Also, the MWR is responsible for e-flows restoration of degraded-rivers in an operation period. Assessment of green, small hydropower stations by the MWR is effective for e-flows release of small hydropower projects. Due to the ineffectiveness of supervision in large dams, ecological civilization constructions for the whole process management are being built. The NEA is responsible for the approval of hydropower projects in the plan and design period, with the assistance of MEP in e-flows assessment. Despite the fact that the NEA is not directly responsible for e-flows implementation, the MEP and NEA worked on e-flows management by jointly issuing several letters. For better e-flows management of hydropower projects, sustainable hydropower assessment guidelines including e-flows assessment and optimization should be published soon.

Table 1. Relevant ministries for environmental flows (e-flows) and their responsibilities.

\begin{tabular}{|c|c|c|c|c|c|}
\hline Ministry & Responsibilities & Plan Period & Design Period & $\begin{array}{l}\text { Construction } \\
\text { Period }\end{array}$ & $\begin{array}{l}\text { Operation } \\
\text { Period }\end{array}$ \\
\hline MEP & $\begin{array}{l}\text { E-flows release determination in } \\
\text { Plan-EIA and EIA of water } \\
\text { relevant projects, and water } \\
\text { pollution prevention. E-flows } \\
\text { release supervision in } \\
\text { operation period }\end{array}$ & Plan-EIA & EIA & $\begin{array}{c}\text { Three } \\
\text { simultaneities }\end{array}$ & $\begin{array}{c}\text { Post-project } \\
\text { EIA }\end{array}$ \\
\hline MWR & $\begin{array}{l}\text { E-flows release pre-assessment } \\
\text { before Plan-EIA and EIA of water } \\
\text { conservancy projects, along with } \\
\text { e-flows recovery in river } \\
\text { ecosystem protection } \\
\text { and restoration }\end{array}$ & $\begin{array}{l}\text { Watershed } \\
\text { planning }\end{array}$ & $\begin{array}{l}\text { Assessment of } \\
\text { water-draw } \\
\text { and utilization }\end{array}$ & $\begin{array}{l}\text { Environmental } \\
\text { protection } \\
\text { measures design } \\
\text { and construction }\end{array}$ & $\begin{array}{l}\text { Green small } \\
\text { hydropower } \\
\text { stations }\end{array}$ \\
\hline NEA & $\begin{array}{c}\text { E-flows release pre-assessment } \\
\text { before Plan-EIA and EIA of } \\
\text { hydropower projects }\end{array}$ & $\begin{array}{l}\text { River hydropower } \\
\text { development plan } \\
\text { and approval }\end{array}$ & $\begin{array}{l}\text { Hydropower } \\
\text { projects } \\
\text { approval }\end{array}$ & $\begin{array}{l}\text { Engineering } \\
\text { construction } \\
\text { supervision }\end{array}$ & $\begin{array}{l}\text { Sustainable } \\
\text { hydropower } \\
\text { assessment }\end{array}$ \\
\hline
\end{tabular}




\subsection{Legal Instruments}

A great number of relevant e-flows documents have been published over the last 10 years (Supplementary Table S1). Despite the fact that the legal framework was already very strict in e-flows management from planning to construction periods, there has been a need for an e-flows assessment of river ecosystems and adaptive management of reservoir regulation during the operation period.

E-flows implementation began in the 1970s, at which time there was no official regulation. It was not until 1987 that the first official regulation of water allocation for the Yellow River was approved and issued by the State Council. The allocation plan is still working now, and the "Regulations on Water Regulation of the Yellow River" was issued in 2006 for the IWRM. The "Technical Guide 2006" was jointly drafted by multiple ministries, and published as a government letter for all rivers in China. The principles and fundamentals of e-flows were established in this guide, which ruled "the minimum flow should not be less than $10 \%$ of the annual average flow in the dam site". The guide leads a series of regulations (Table 2) drafted by the MWR and NEA for e-flows assessment, and the minimum flow releases have been guaranteed since 2006.

Table 2. Regulations, guidelines and codes on e-flows in China.

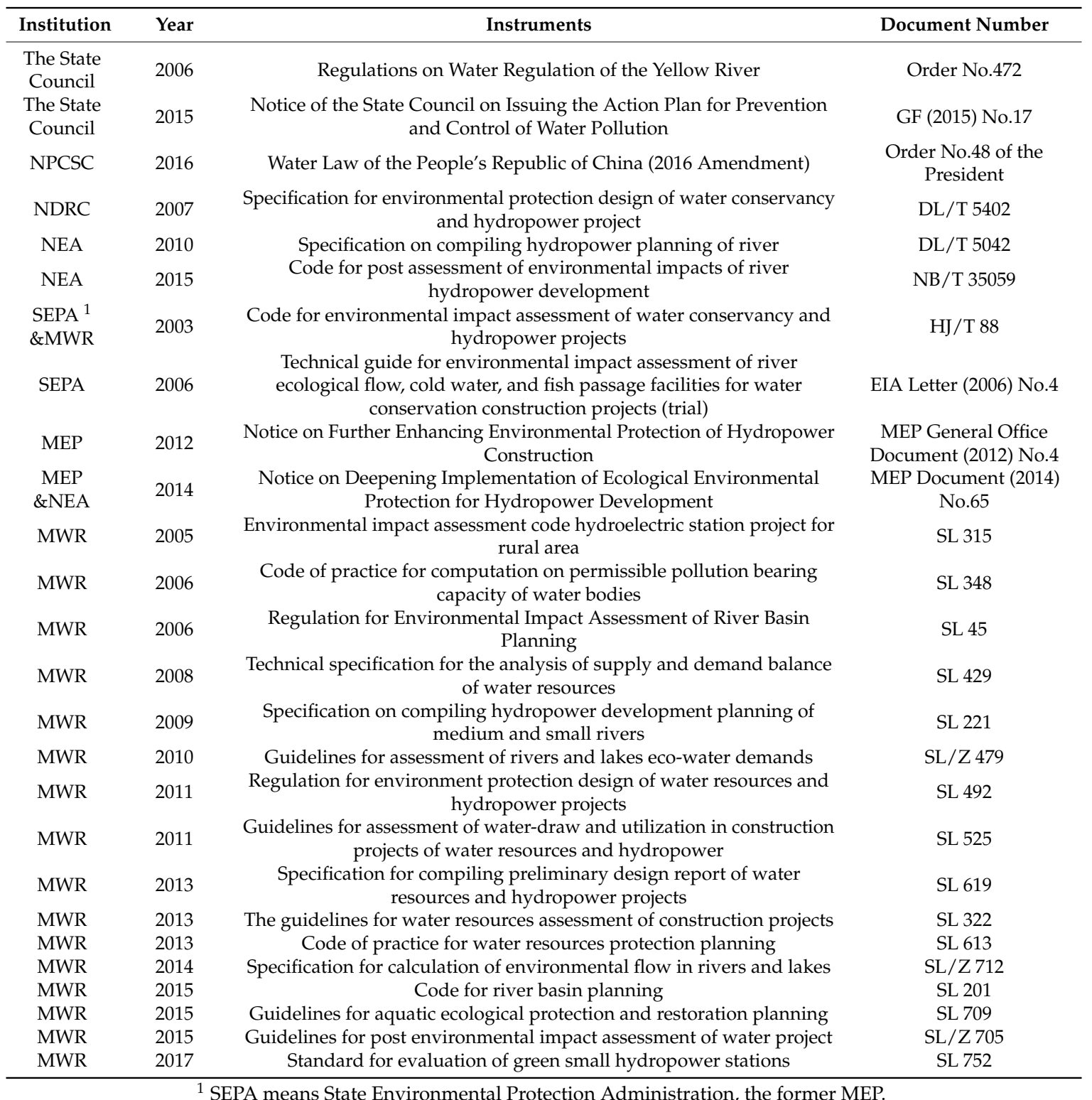

${ }^{1}$ SEPA means State Environmental Protection Administration, the former MEP. 
However, e-flows were not fully implemented due to the lack of monitoring and supervision. It was not until recent years that the central governments realized the importance of guaranteeing e-flows and began to strengthen inspection and supervision by penalized local governments, stakeholders, and hydro-plant owners. At present, the "Action Plan for Prevention and Control of Water Pollution and the Water Law of the People's Republic of China (2016 Amendment)" are two major laws, acting as the top implementation guides, which stress the importance of e-flows. More appropriate ways of enforcing and promoting sustainable e-flows implementation are under discussion, such as renewing the "Technical Guide 2006", improving the minimum flow constraints from 10\% of the annual average flow, and learning from Swiss Green Hydropower to build the "Standard for Evaluation of Green Small Hydropower Stations". This standard is useful for promoting green development by enforcing e-flows releases for small hydropower stations. As a result, there are rewards to raising hydroelectricity prices for those stations which have been awarded green certifications.

\section{Scientific Basis and Validation}

\subsection{Common Methods}

There have been more than 200 different generic methods developed to calculate e-flows around the world [22,23]. Each method should be used in different situations depending on the specific purposes and the type of issues being addressed. For the Chinese government, there are some common and proven methods used in the planning and design period, which were suggested in the legal instruments. Since the release of the "Technical Guide 2006", hydrological, hydraulic and habitat simulation methods have been recommended in the assessment of e-flows release, and the assessment results of all of the projects can be found on the official website of the MEP.

In the beginning, hydrological based methods (e.g., Tennant, 7Q10, MAF, etc.) were widely used due to insufficient ecological and topographic data, and $10 \%$ of the annual average flow was set as the minimum flow, even though it was not a scientific-driven method. In continuous implementation and monitoring, hydraulic methods and habitat simulation methods (e.g., R2cross, Wetted parameter method, eco-hydraulics method, etc.) were applied and improved (e.g., ecological hydraulic radius) in practice. Currently, e-flows are determined by expert judgement. All of the environmental objectives should be considered in the process. Flow duration curves were created as an accumulation of the flows for each objective. In addition, other factors such as natural flow regime, flood pulses and ecological regulation were integrated into e-flows assessment results before approval [24].

There are additional methods not suggested in the guidelines, such as the flow and ecological response method [25]. The scientific basis of these methods are flow-ecology relationships, which require long-term monitoring of ecological and hydrological data, multi-disciplinary collaboration, and extensive financial support. For river protection, these methods were useful for considering all the water users. This study aims to improve the existing management system by promoting a more holistic approach, and by determining how to apply and promote e-flows adaptive management for environmental sustainable development.

\subsection{Validation Practices}

There were many practices and validations described in the "Technical Guide 2006" and the letters which followed. As approved by the MEP, e-flows were holistically considered for some dam projects including hydropower projects (Supplementary Table S2) and water conservancy projects (Supplementary Table S3) in the past five years. Five representative hydropower projects (Duobu, Xiasajiang I, Yebatan, Ma'erdang and Batang Hydropower Project) and five water conservancy projects (Pingtan and Minjiang Estuary Water Resources Allocation Project, Huangshui North Canal Phase II Irrigation project, A'gang Reservoir Project, Nalinggele Water control project and Chao'er River to Xiliaohe River Water Transfer Project) were chosen from all the projects where e-flows were implemented to explain the effectiveness of e-flows assessment and release (Figure 1). 


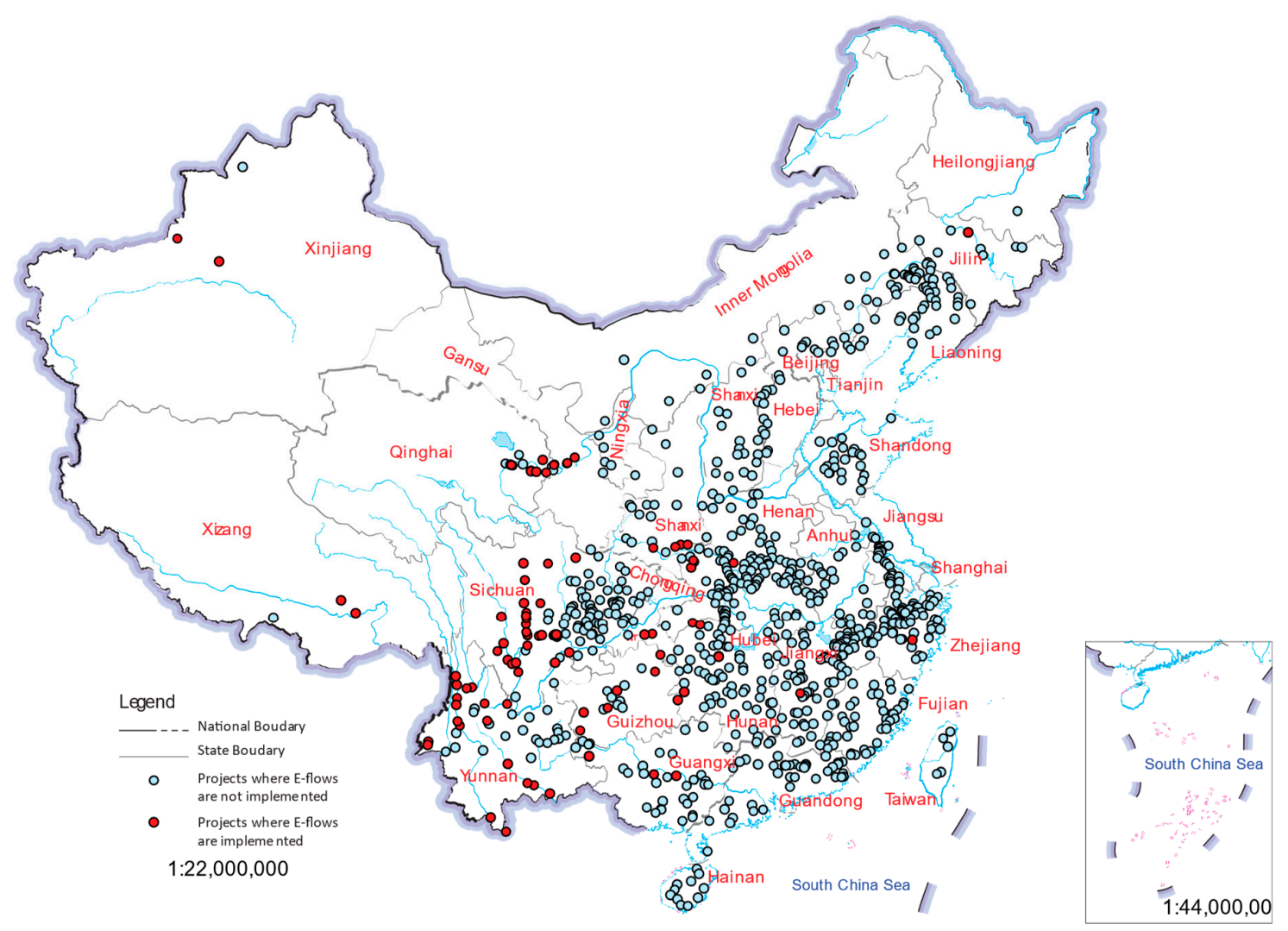

Figure 1. Distribution map of hydropower and water conservancy projects approved by the Ministry of Environment Protection (MEP).

At least two periods of the flow process were considered for the projects (Table 3), and the flood peaks were required to be generated in special periods such as fish spawning seasons. The Ma'erdang hydropower station must maintain natural flow without inner day peak regulation in the fish spawning period (e.g., Gymnocypris eckloni Herzensten, Gymnodiptychus pachycheilus, Triplophysa pappenheimi). For the Batang hydropower station, ecological operation was required for 10 days every month during the fish spawning period. Water transfer projects were among the most complex of water conservancy projects, because multi-reservoirs and the spatial transfer of water resources were involved (e.g., the Chao'er River to Xiliaohe River Water Transfer Project). On the basis of the above, it can be concluded that e-flows have been enhanced after 10 years of practice, and e-flows implementation have become much more complex.

However, e-flows implementation was less effective when reservoir inflow was less than the required e-flows. In order to solve this problem and increase the reliability of e-flows release, we have performed some experiments such as e-flows regulation, cascade reservoir operation, integrated watershed resource management. 
Table 3. E-flows validation practices of hydropower and water conservancy projects.

\begin{tabular}{|c|c|c|c|}
\hline Project Name & Project Type & Operation Year & E-flows \\
\hline Duobu & Hydropower & 2012 & $\begin{array}{l}\text { No peak load regulation from November to the } \\
\text { next September. } \\
\text { E-flows release equals reservoir inflow, while inflow } \\
\text { is less than } 80 \mathrm{~m}^{3} / \mathrm{s} \text {. }\end{array}$ \\
\hline Xiasajiang I & Hydropower & 2014 & $\begin{array}{l}\qquad>28 \mathrm{~m}^{3} / \mathrm{s} \text { in April to July. } \\
22 \mathrm{~m}^{3} / \mathrm{s} \text { from August to the next March. } \\
\text { E-flows release equals reservoir inflow while inflow } \\
\text { is less than e-flows. }\end{array}$ \\
\hline Yebatan & Hydropower & 2016 & $\begin{array}{l}\qquad>132 \mathrm{~m}^{3} / \mathrm{s} \text { in normal period. } \\
>272 \mathrm{~m}^{3} / \mathrm{s} \text { in March and April. } \\
>405 \mathrm{~m}^{3} / \mathrm{s} \text { in August and September. } \\
\text { In fish spawning period (March, April, August and } \\
\text { September), generate } 10 \text { days ecological operation } \\
\text { and release e-flows as reservoir inflow without inner } \\
\text { day peak regulation. }\end{array}$ \\
\hline Ma'erdang & Hydropower & 2016 & $\begin{array}{l}>145 \mathrm{~m}^{3} \text { /s from January to March, and July } \\
\text { to November. } \\
\text { Maintaining natural flow from April to June } \\
\text { (spawning period of Gymnocypris eckloni Herzensten, } \\
\text { Gymnodiptychus pachycheilus, Triplophysa pappenheimi), } \\
\text { without inner day peak regulation. }\end{array}$ \\
\hline Batang & Hydropower & 2017 & $\begin{array}{l}>74 \mathrm{~m}^{3} / \mathrm{s} \text { in December (normal water use period). } \\
\qquad>138 \mathrm{~m}^{3} / \mathrm{s} \text { in normal period. } \\
>277 \mathrm{~m}^{3} / \mathrm{s} \text { from March to April, and }>413 \mathrm{~m}^{3} / \mathrm{s} \text { from } \\
\text { August to September, with at least 1-time ecological } \\
\text { operation (lasting } 10 \text { days longer) every month. }\end{array}$ \\
\hline $\begin{array}{l}\text { Pingtan and } \\
\text { Minjiang Estuary }\end{array}$ & $\begin{array}{l}\text { Water Resources } \\
\text { Allocation Project }\end{array}$ & 2016 & $\begin{array}{l}>13.8 \mathrm{~m}^{3} / \mathrm{s} \text { from October to the next March. } \\
>23.2 \mathrm{~m}^{3} / \mathrm{s} \text { from April to September. }\end{array}$ \\
\hline $\begin{array}{l}\text { Huangshui North } \\
\text { Canal Phase II }\end{array}$ & Irrigation project & 2016 & $\begin{array}{l}>4.0 \mathrm{~m}^{3} / \mathrm{s} \text { from November to the next April. } \\
>1.69 \mathrm{~m}^{3} / \mathrm{s} \text { from May to October. }\end{array}$ \\
\hline $\mathrm{A}^{\prime}$ gang & Reservoir Project & 2016 & $\begin{array}{c}>2.08 \mathrm{~m}^{3} / \mathrm{s} \text { from November to the next May. } \\
>6.23 \mathrm{~m}^{3} / \mathrm{s} \text { from June to October. } \\
>5.48 \mathrm{~m}^{3} / \mathrm{s} \text { in normal period. }\end{array}$ \\
\hline Nalinggele & Water control project & 2017 & $\begin{array}{l}>11.82 \mathrm{~m}^{3} / \mathrm{s} \text { from May to September. } \\
\text { Generate 1-time flood peak in June and September. }\end{array}$ \\
\hline $\begin{array}{l}\text { Chao'er River to } \\
\text { Xiliaohe River } \\
\text { Water Transfer } \\
\text { Project }\end{array}$ & Water transfer project & 2017 & $\begin{array}{l}\text { Wendegen Reservoir: } 14.27-22.65 \mathrm{~m}^{3} / \mathrm{s} \text {. } \\
\text { Chaole Reservoir: } 15.46-24.54 \mathrm{~m}^{3} / \mathrm{s} \text { (April to } \\
\text { September), }>5.2 \mathrm{~m}^{3} / \mathrm{s} \text { (October to the next March). } \\
\text { Release reservoir inflow while inflow is less than } \\
\text { e-flows, the minimum flow is } 1.28 \mathrm{~m}^{3} / \mathrm{s} \text {. }\end{array}$ \\
\hline
\end{tabular}

\subsection{Pilot of the Three Gorges Reservoir}

More than 30 large dams have been constructed along the upper reaches of the Yangtze River and its tributaries. The natural flow and thermal regime in the downstream of the Three Gorges Dam (TGD) were affected, which were required for the reproduction of four major Chinese carps [26]. The ecological operation of the Three Gorges Reservoir (TGR) began from 2011, aimed at facilitating the breeding of four major species of Chinese carp (black carp, grass carp, silver carp, and bighead carp). In combination with the requirements for emptying the storage capacity, and in accordance with the upstream water regime, 1-2 rising processes (lasting for about 10 days each) were completed throughout the operation. A discharge of $11,000 \mathrm{~m}^{3} / \mathrm{s}$ at the Yichang Hydrometrical Station was used as its initial discharge; this was increased by $8000 \mathrm{~m}^{3} / \mathrm{s}$ within six days, and finally increased to $19,000 \mathrm{~m}^{3} / \mathrm{s}$, with an average daily rising amplitude of the water level of no less than $0.4 \mathrm{~m}$. Monitoring results for an ecological operation test showed that it promoted the breeding and increased the amount of eggs spawned during the operation period [27]. Aside from an operation for fish, an ecological operation for estuary desalinization was conducted by the TGR from 21 February to 3 March 2014, and mitigated the serious impact caused by salty tide intrusion upstream, while also relieving the water shortages in the middle and lower Yangtze River. Beginning in 2017, an ecological operation based 
on cascade reservoirs (TGR and Gezhouba Reservoir in the middle stream, Xiangjiaba Reservoir and Xiluodu Reservoir in the upstream) has been planned for multiple environmental objects.

\section{Conclusions}

Since the first minimum flow practice in the 1970s in northwestern China, e-flows science and implementation in China have been greatly improved through sustainable water use practices and scientific research. Despite the fact that e-flow practices and research have been conducted, they are still not used as an operational implementation measure in China. After ecological civilization was proposed, so as to realize the 2030 SDG and "beautiful China" goals, more practices and pilot demonstrations involving ecological watersheds, sustainable hydropower assessment, and sustainable development in the Yangtze River Economic Zone, and the River Chief have been performed. At present, e-flows provide a sound basis for the complete achievement of these strategic goals. E-flows are society's response to the progressive deterioration of aquatic ecosystems due to intensive use of water resources. There is no doubt that e-flows are an essential part of maintaining or restoring aquatic ecosystems where hydrological alterations have led to their degradation.

It is important to improve the implementation efficiency of e-flows. Challenges continue to exist in e-flows science and implementation. Various researchers have demonstrated the importance of flow human activities on regional aquatic ecosystems. Different environmental disturbance factors were proposed in the research, especially in the determination, management policies and implementation strategies of e-flows. There are two main urgent difficulties for further establishing e-flows in China. Firstly, the e-flows concepts were revised in 2017, and China's ecological flow concept needs to be revised for ecological civilization and international hydropower investment. There is no common method for e-flows determination considering spatial and temporal differences in China, such as seasonal rivers, mountain rivers, damming rivers. Thus, an e-flows calculation framework based on hydrogeological conditions, geomorphological features, climatic characteristics, and the impacts of human activities would support sustainable water management. Secondly, e-flows relevant issues involve multiple ministries in China, which is one of the greatest difficulties in implementation. In addition, the amount of policies, norms and industry guidance on how to determine, manage and implement the e-flows in China is increasing. Although there are comprehensive management regulations to supervise the implementation, the process of establishing reasonable e-flows standards is beset with difficulties. For example, the deficiency of hydrological data, the difficulty in obtaining habitat information, and the high budget for monitoring ecological data do impede the pursuit of e-flows. Therefore, in order to ensure the rational formulation and effective implementation of e-flows, multi-disciplinary scientists, engineers and managers are required to work together. Fortunately, the MEP and MWR have reached a common view in e-flows and gap reduction. A watershed monitoring system is planned for e-flows implementation to conduct flow-ecology relationships.

The effectiveness of e-flows implementation is a complex and challenging task involving multiple aspects. It is based not only on research on the theoretical knowledge of e-flows, but also on the basis of the actual engineering conditions and the coordination of multiple parties for development. From this study, development history of e-flows in China and diverse experiences of e-flows practitioners across regions and disciplines have been brought together. It provides evidence of the national dimensions of freshwater ecosystem degradation, and decades of research, engineers, managers and other stakeholders to protect aquatic ecosystems by e-flows implementation. In spite of shortcomings, it helps researchers to better understand some specific problems in China's e-flows implementation. Furthermore, incorporating e-flows into ecological civilization could build further momentum for e-flows implementation to be the central element of sustainable water resource management.

Supplementary Materials: The following are available online at http:/ /www.mdpi.com/2073-4441/11/3/433/s1, Table S1: E-flows documents in China, Table S2: E-flows of Hydropower Projects, Table S3: E-flows of Water Conservancy Projects.

Author Contributions: Writing—original draft preparation, A.C.; writing—review and editing, M.W. 
Funding: This research was funded by National Key Research and Development Program of China [No. 2016YFE0102400].

Acknowledgments: Great thanks to Michael E. McClain from IHE Delft Institute for Water Education (Netherlands) for the editing of the English language and style of this manuscript. The authors also thank the anonymous reviewers for their very valuable comments.

Conflicts of Interest: The authors declare no conflict of interest.

\section{References}

1. Matthews, J.H.; Forslund, A.; McClain, M.E.; Tharme, R.E. More than the fish: Environmental flows for good policy and governance, poverty alleviation and climate adaptation. Aquat. Procedia 2014, 2, 16-23. [CrossRef]

2. Peñas, F.J.; Juanes, J.A.; Galván, C.; Medina, R.; Castanedo, S.; Álvarez, C.; Bárcena, J.F. Estimating minimum environmental flow requirements for well-mixed estuaries in Spain. Estuar. Coast. Shelf Sci. 2013, 134, 138-149. [CrossRef]

3. Davies, P.M.; Naiman, R.J.; Warfe, D.M.; Pettit, N.E.; Arthington, A.H.; Bunn, S.E. Flow-ecology relationships: Closing the loop on effective environmental flows. Mar. Freshw. Res. 2014, 65, 133-141. [CrossRef]

4. Acreman, M.C.; Overton, I.C.; King, J.; Wood, P.J.; Cowx, I.G.; Dunbar, M.J.; Kendy, E.; Young, W.J. The changing role of ecohydrological science in guiding environmental flows. Hydrol. Sci. J. 2014, 59, 433-450. [CrossRef]

5. Vivian, L.M.; Marshall, D.J.; Godfree, R.C. Response of an invasive native wetland plant to environmental flows: Implications for managing regulated floodplain ecosystems. J. Environ. Manag. 2014, 132, 268-277. [CrossRef] [PubMed]

6. Summers, M.F.; Holman, I.P.; Grabowski, R.C. Adaptive management of river flows in Europe: A transferable framework for implementation. J. Hydrol. 2015, 531, 696-705. [CrossRef]

7. Erfani, T.; Binions, O.; Harou, J.J. Protecting environmental flows through enhanced water licensing and water markets. Hydrol. Earth Syst. Sci. 2015, 19, 675-689. [CrossRef]

8. Kelly, O.M.; Colin, B.T.; Jeffrey, C.; Cole, H.S.; Galbraith, C.J.; Blakeslee, L.H.; Christopher, L.H. An integrated riverine environmental flow decision support system (REFDSS) to evaluate the ecological effects of alternative flow scenarios on river ecosystems. Fundam. Appl. Limnol. 2015, 186, 171-192.

9. Pahl-Wostl, C.; Arthington, A.; Bogardi, J.; Bunn, S.E.; Hoff, H.; Lebel, L.; Nikitina, E.; Palmer, M.; Poff, L.N.; Richards, K.; et al. Environmental flows and water governance: Managing sustainable water uses. Curr. Opin. Environ. Sustain. 2013, 5, 341-351. [CrossRef]

10. Wohl, E. Environmental flows: Saving rivers in the third millennium. Biol. Conserv. 2013, 166, 33. [CrossRef]

11. Poff, N.L. Beyond the natural flow regime? Broadening the hydro-ecological foundation to meet environmental flows challenges in a non-stationary world. Freshw. Biol. 2017, 1-11. [CrossRef]

12. Arthington, A.H.; Bhaduri, A.; Bunn, S.E.; Jackson, S.E.; Tharme, R.E.; Tickner, D.; Young, B.; Acreman, M.; Baker, N.; Capon, S.; et al. The Brisbane Declaration and Global Action Agenda on Environmental Flows (2018). Front. Environ. Sci. 2018, 6, 1-15. [CrossRef]

13. Ang, C.; Miao, W.; Kaiqi, C.; Zhiyu, S.; Chen, S.; Pengyuan, W. Main issues in environmental protection research and practice of water conservancy and hydropower projects in China. Water Sci. Eng. 2017, 4, 312-323.

14. Miao, W.; Ang, C. Practice on ecological flow and adaptive management of hydropower engineering projects in China from 2001 to 2015. Water Policy 2017, 2, 336-354.

15. Ang, C.; Xin, S.; Wengen, L.; Kaiqi, C. Review study on instream ecological base flow in China. J. China Inst. Water Resour. Hydropower Res. 2016, 6, 401-411.

16. Ma, L.; Zhang, X.; Wang, H.; Qi, C. Characteristics and Practices of Ecological Flow in Rivers with Flow Reductions Due to Water Storage and Hydropower Projects in China. Water 2018, 10, 1091. [CrossRef]

17. Wang, H.; Wang, H.; Hao, Z.; Wang, X.; Liu, M.; Wang, Y. Multi-Objective Assessment of the Ecological Flow Requirement in the Upper Yangtze National Nature Reserve in China Using PHABSIM. Water 2018, 10, 326. [CrossRef]

18. Bhaduri, A.; Bogardi, J.; Leentvaar, J.; Marx, S. The Global Water System in the Anthropocene: Challenges for Science and Governance; Springer: Delft, The Netherlands, 2014; pp. 1-14. 
19. Ang, C.; Miao, W.; Chen, S.; Xingnan, Z.; Pengyuan, W. Review of method for calculation of river ecological base-flow and study on its assessment framework. Water Resour. Hydropower Eng. 2017, 2, 97-105.

20. Ang, C.; Chen, S.; Miao, W.; Pengyuan, W. Recommendation on ecological water demand management in China. Sci. Technol. Rev. 2016, 22, 11.

21. Xiao, L.; Zhao, R. China's new era of ecological civilization. Science 2017, 358, 1002-1008.

22. Tharme, R.E. A global perspective on environmental flow assessment: Emerging trends in the development and application of environmental flow methodologies for rivers. River Res. Appl. 2003, 19, 397-441. [CrossRef]

23. Pastor, A.V.; Ludwig, F.; Biemans, H.; Hoff, H.; Kabat, P. Accounting for environmental flow requirements in global water assessments. Hydrol. Earth Syst. Sci. 2014, 18, 5041-5059. [CrossRef]

24. Chen, A.; Sui, X.; Wang, D.; Liao, W.; Ge, H.; Tao, J. Landscape and avifauna changes as an indicator of Yellow River Delta Wetland restoration. Ecol. Eng. 2016, 86, 162-173. [CrossRef]

25. Wang, J.; Dong, Z.; Liao, W.; Li, C.; Feng, S.; Luo, H.; Peng, Q. An environmental flow assessment method based on the relationships between flow and ecological response: A case study of the Three Gorges Reservoir and its downstream reach. Sci. China Technol. Sci. 2013, 56, 1471-1484.

26. Harwood, A.; Johnson, S.; Richter, B.; Locke, A.; Yu, X.; Tickner, D. Listen to the River: Lessons from a Global Review of Environmental Flow Success Stories; WWF-UK: Surrey, UK, 2017. Available online: https: / /www.wwf.org.uk/what-we-do/projects/environmental-flows (accessed on 18 September 2017).

27. Shouren, Z. Reflections on the Three Gorges Project since its operation. Engineering 2016, 2, 389-397.

(C) 2019 by the authors. Licensee MDPI, Basel, Switzerland. This article is an open access article distributed under the terms and conditions of the Creative Commons Attribution (CC BY) license (http:/ / creativecommons.org/licenses/by/4.0/). 